\title{
The Effects of Taurine on Central Nervous System
}

\author{
Ayris GÖKÇEOĞLU ${ }^{1, a, *}$, Gül Fatma YARIM ${ }^{1, b}$, Murat YARIM ${ }^{2, c}$
}

\begin{abstract}
${ }^{1}$ Department of Biochemistry, Faculty of Veterinary Medicine, Ondokuz Mayis University, Samsun, Turkey.
${ }^{2}$ Department of Pathology, Faculty of Veterinary Medicine, Ondokuz Mayis University, Samsun, Turkey. aORCID: 0000-0002-2944-9122; bORCID: 0000-0003-4050-429X; 'ORCID: 0000-0002-0636-4214.
\end{abstract}

Tarihi: 11.06.2020

Kabul Tarihi: 26.10 .2020

Abstract: Taurine is a neuroprotective amino acid which regulates gene expression of neural stem and precursor cells, modulating inflammatory pathways in the central nervous system, suppressing apoptosis, antioxidant effect and controlling cell volume and water content of neurons. Taurine suppresses endoplasmic stress-mediated apoptosis through the ionotropic taurine receptor and the metabotropic taurine receptor. Due to its neuroprotective effect, taurine is successfully used in the prophylaxis and treatment of neurodegenerative disorders. This review aims to present current scientific information of the effects of taurine on the central nervous system and its use in alleviating central nervous system disorders

Keywords: Central nervous system, Neuroprotective, Taurine.

\section{Taurinin Merkezi Sinir Sistemi Üzerindeki Etkileri}

Özet: Taurin, nöral kök ve prekürsör hücrelerin gen ekspresyonunu düzenleyen, merkezi sinir sistemindeki enflamatuar yolları modüle eden, apoptozu baskılayan, antioksidan etkili ve nöronların hacmini ve su içeriğini kontrol eden nöroprotektif bir amino asittir. Taurin, iyonotropik taurin reseptörü ve metabotropik taurin reseptörü aracılığıyla endoplazmik stres aracılı apoptozu baskılamaktadır. Nöroprotektif etkisi nedeniyle taurin nörodejeneratif bozuklukların profilaksisinde ve tedavisinde başarıyla kullanılmaktadır. Bu derlemenin amacı, taurinin merkezi sinir sistemi üzerindeki etkilerini ve taurinin merkezi sinir sistemi hasarlarını hafifletmede kullanımını konusunda güncel bilimsel bilgiyi sunmaktır.

Anahtar Kelimeler: Merkezi sinir sistemi, Nöroprotektif, Taurin.

\section{Introduction}

Taurine is synthesized from the cysteine in the organism with molecular formula $\mathrm{C}_{2} \mathrm{H}_{7} \mathrm{NO}_{3} \mathrm{~S}$ and molecular weight $125.15 \mathrm{~g} \mathrm{~mol}^{-1}$ (Ripps and Shen, 2012). Taurine was first isolated from ox bile in 1827 by German scientists Friedrich Tiedemann and Leopold Gmelin (Tiedemann and Gmelin, 1827). The first step in the synthesis of taurine is the conversion of methionine to cysteine through transsulfuration. Cysteine is oxidized to cysteine sulfinic acid, and also converted to cysteamine, and cysteamine is oxidized to hypotaurine. Taurine is synthesized as a final product by the oxidation of hypotaurine (Menzie et al., 2013; Ripps and Shen, 2012). The major steps of taurine biosynthesis were presented in Figure 1.

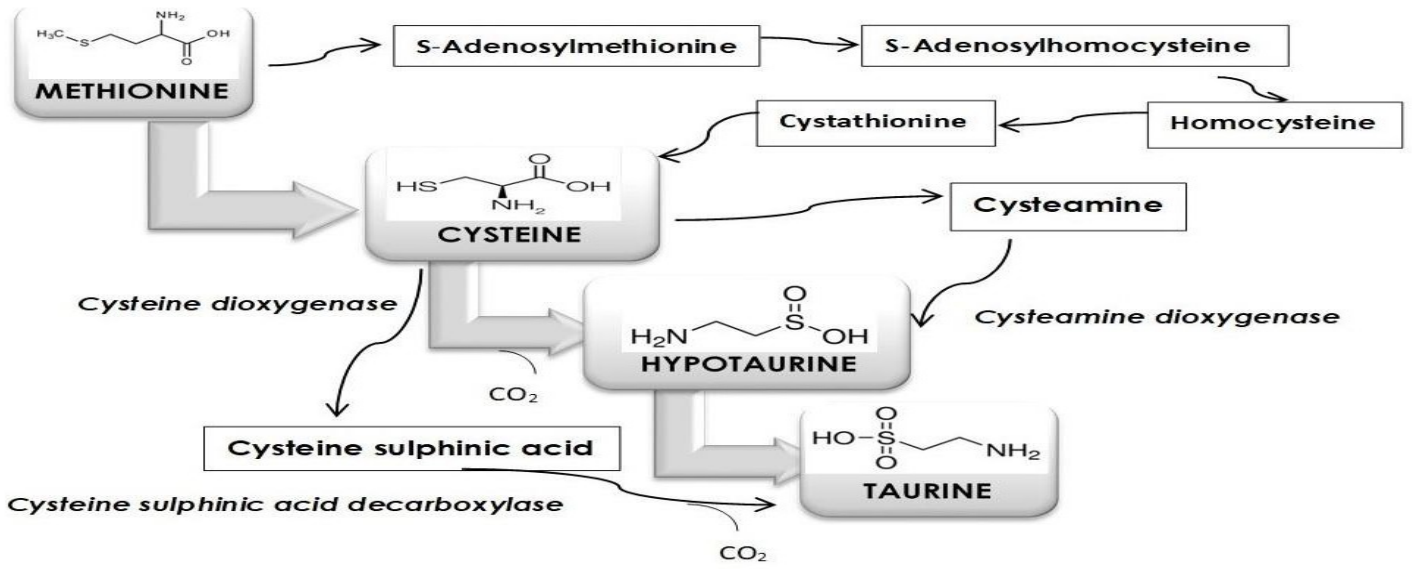

Figure 1. The major steps of taurine biosynthesis. ( Adapted from Menzie et al., 2013). 


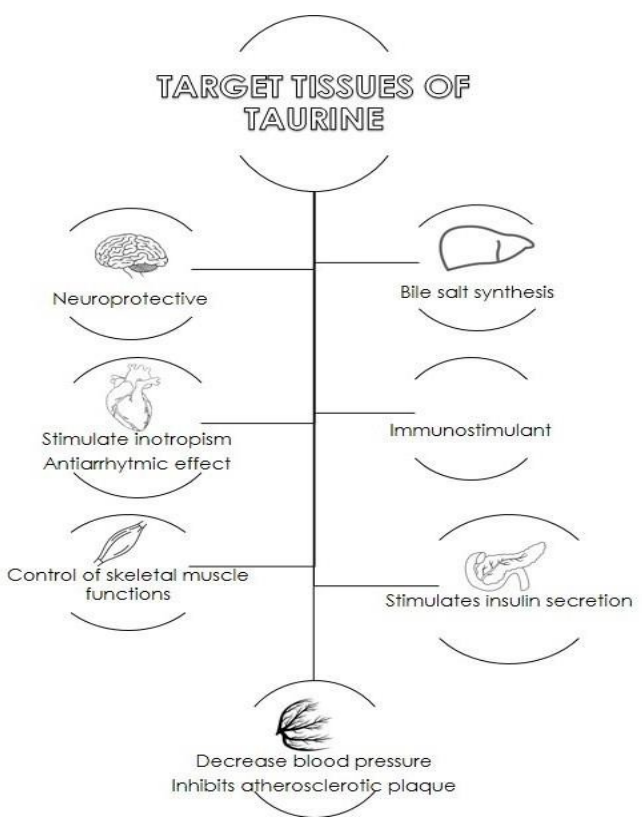

Figure 2. The effects of taurine in various tissues and organs (Adapted from De Luca et al., 2015)

General effects of the taurine on organism: Taurine controls the membrane excitability of the skeletal muscle and phenotypic properties (De Luca et al., 2015). Taurine has important effects such as neuromodulator, antioxidant, anti-inflammatory, antiarrhythmic, and anti-cholestatic (Chen et al., 2020; Jangra et al., 2020; Liu et al., 2017). Taurine is an effect on glycine receptors and reduces glycine affinity in postsynaptic neurons (Chan et al., 2013). Taurine inhibits hypothalamic leptin resistance (Camargo et al., 2015). Taurine stimulates

GABAA receptor-mediated action potentials in GABAergic neurons (Jia et al., 2008). The effects of taurine in various tissues and organs were presented in Figure 2.

The effects of taurine on the central nervous system: Taurine is found in the central nervous system and the neuroprotective effect of taurine has been reported by many studies (Ananchaipatana-Auitragoon et al., 2015; Foos and Wu, 2002; Reeta et al., 2017; Vitvitsky et al., 2011; Wang et al., 2007; Wu et al., 2005; Wu and Prentice, 2010; Zhang et al., 2017). Taurine shows these effects by promoting proliferation and survival of neural progenitor cells, acting as neuro-osmolyte, protecting against endoplasmic stress and neurotoxicity, and providing the cellular integrity of auditory neurons. (Hernández-Benítez et al., 2010; Pan et al., 2012; Rak et al., 2014; Hackett et al., 2016). A schematic view of the neuroprotective effect of taurine is presented in Figure 3.

The effects of taurine on proliferation and survival of neural cells: Taurine, which contributes to proliferation and survival of neural progenitor cells, is suggested to be a trophic factor for these cells. It has been reported

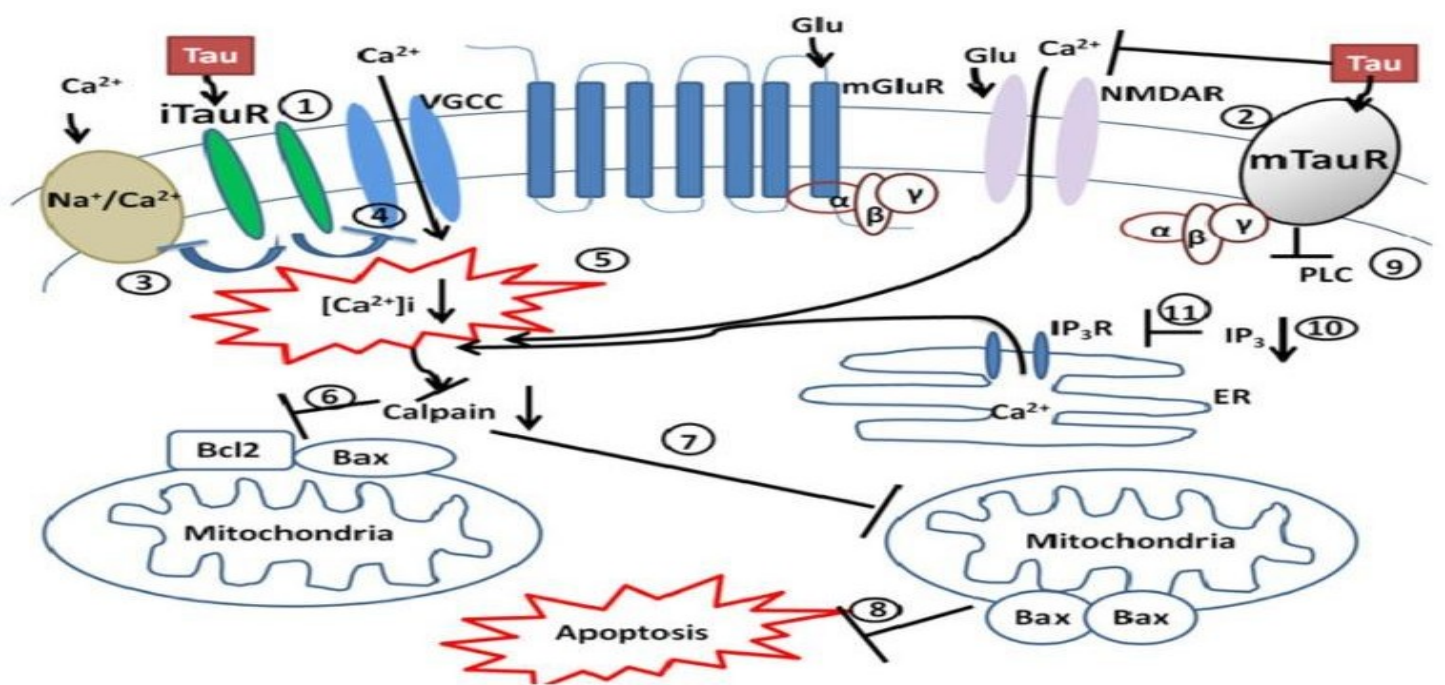

Figure 3. A schematic view of the neuroprotective effect of taurine via taurine receptors (1) Activated ionotropic taurine receptor (iTauR) and/or (2) metabotropic taurine receptor (mTauR) inhibits, sodium/calcium exchanger (3); (4) The inhibition of voltage-dependent calcium channels (VGCC) due to taurine-induced hyperpolarization causes intracellular calcium deprivation (5). Decreased intracellular calcium inhibits calpain and the calpain-induced breakdown of Bcl-2 and Bax is shaped (6). (7) Inhibition of the Bax homodimer leads to the inhibition of the mitochondrion-mediated death cascade (8). (9) Phospholipase C (PLC) is inhibited by the active mTauR (mTauR: bound to the inhibitor G protein) and results in reduced production of IP3 which attenuates calcium release from the endoplasmic reticulum (ER) (10) and causes ER stress and ER stress-mediated apoptosis (Menzie et al., 2013).

that the increasing effect of taurine in neural precursor cells from the subventricular zone of the adult mouse brain (Hernandez et al., 2012) is 5 times greater than in embryonic cells (HernándezBenítez et al., 2010). The researchers linked this finding to the fact that embryonic cells are growing in an environment rich in taurine. Taurine in developing brain tissue plays a role in neural stem/progenitor cell proliferation via ERK1/2 pathways and affects protein levels associated with 
synapse development (Shivaraj et al., 2012). This study is stated to be the first evidence showing the effect of taurine on early postnatal neuronal development using a combination of in vitro, exvivo, and in vivo systems. Similarly, taurine has been reported to stimulate the proliferation and neurite outgrowth of neural stem cells, which was completely abolished by sonic hedgehog inhibitor cyclopamine, into spiral ganglia by activating the sonic hedgehog signaling pathway. It has been emphasized that and the important role of sonic hedgehog pathway underlying the protective effect of taurine on the auditory neural system (Huang et al., 2018).

The effects of taurine as neuro-osmolyte: Increased extracellular taurine levels during perfusions with Krebs-ringer bicarbonate in the rat dentate gyrus have been determined. This result indicates the possible involvement of taurine in osmoregulatory processes in the brain (Solís et al., 1988). Taurine functions as an osmolyte by controlling membrane content and water content of neurons during ion entry and exit by membrane depolarization of neuronal transmission in brain tissue (Olson and Martinho, 2006). Taurine, which is found intensely in the granular and molecular layers of the cerebellum, is defined as neuro-osmolyte (Hackett et al., 2016). During the local osmotic alteration, increased cellular hydration was accompanied by a marked increase in extracellular taurine levels in the rat brain has been demonstrated. The specificity, sensitivity, and reversibility of this increase in extracellular taurine strongly suggest a functional role in osmoregulation in the brain under normal as well as pathological conditions (Wade et al., 1988).

The effect of taurine against endoplasmic stress: Taurine has been reported to have a protective role against activation of endoplasmic stress pathways in rat primary cortical neuronal culture. It has been suggested that taurine exerts this effect by inhibiting the upregulation of caspase12 and GADD153 / CHOP caused by hypoxia/reoxygenation (Pan et al., 2012). Taurine release in mouse hippocampal slices has been shown that regulated by ionotropic glutamate and the adenosine receptors and may counteract any excitotoxic effects of glutamate, particularly in the developing hippocampus (Oja and Saransaari, 2013). The levels of the endoplasmic reticulum stress protein markers GRP78, caspase-12, CHOP, and $\mathrm{p}$-IRE-1 which has been markedly increased in vitro and in vivo model of rat focal middle cerebral artery occlusion significantly has been declined after taurine administration (Gharibani et al., 2013).

The effects of taurine on cellular integrity of neurons: Recently, taurine has been linked to neurite outgrowth, synaptogenesis, and synaptic transmission during the early stages of brain development in both vertebrate and invertebrate species (Mersman et al., 2020). Taurine protects the cellular integrity of auditory neurons and also promotes cellular survival (Rak et al., 2014). Hypoxic pulses given to the substantia nigra by the microdialysis probe have been shown to increase the extrasynaptic taurine level and decrease the taurine level as the osmolarity increases and it has been suggested that the non-synaptic taurine pool which is in substantia nigra plays a role in the defense of nigral cells in Parkinson's disease (Morales et al., 2007). Glial cells secrete taurine to prevent the harmful effects of extracellular hypotonicity on cell volume (Cardin et al., 2003; Deleuze et al., 2000).

Preventive effects of taurine against neurotoxicity: Taurine has a neuroprotective effect against glutamate-induced neurotoxicity (Wu et al., 2005). Taurine inhibits not only the electrical activity of vasopressin neurons but also acts as an inhibitor of both central and peripheral vasopressin secretion during different physiological states (Engelmann et al., 2001). Taurine pretreatment has been shown a protective effect against unconjugated bilirubin-induced damage via reversal of the increased intracellular free calcium ion levels in primary neuronal cultures in a concentrationdependent manner (Zhang et al., 2010). The protective role of taurine treatment at 20 and $1 \mathrm{mM}$ concentrations through activation of GABAA receptors in 1-methyl-4-phenylpyridinium $\left(\mathrm{MPP}^{+}\right)$ induced neurotoxicity rat model has been determined (O'Byrne and Tipton, 2000). Vohra et al. (2001) have reported that taurine protects neurons from the oxidative stress induced by carbon tetrachloride toxicity in a dose-dependent manner.

The use of taurine in central nervous system disorders: Increasing evidence has been indicated that the important roles of taurine administration in alleviating and treating central nervous system damage. Taurine has been reported to enhance the viability and proliferation of mouse cochlear neural stem cell cultures (Wang et al., 2015). Taurine reduces white matter damage and hippocampal neuronal death by suppressing calpain activation and protecting against gray and white matter damage in closed head-trauma rats ( $\mathrm{Gu}$ et al., 2015). Taurine reinforcement in neural stem and precursor cells derived from mesencephalon of mouse embryos regulates cell proliferation and survival, gene expression of neural stem and precursor cells involved in adhesion and mitochondrial functions (Pasantes-Morales et al., 2015). It has been reported that taurine promote axonal regeneration in the spinal cord injury using 
lampreys as an animal model (Sobrido-Cameán et al., 2020).

Taurine supplementation alleviates white matter damage by reducing brain edema, hemorrhagic lesion volume, and neuronal damage (Zhao et al., 2018; Seki et al. (2005) have suggested that taurine administration alleviates neuronal damage, inflammation, and white matter damage by upregulating the content of hydrogen sulfide in tissues around the hematoma and by suppressing P2X7R receptor expression. In this mentioned work, it has been determined that cerebrospinal fluid taurine concentration increased 1.8-fold in severe traumatic brain injury and declined to a control level of 67 hours after injury.

Taurine has been suggested to have an important potential in primary cortical neuron culture to reducing nickel-induced lactate dehydrogenase release, production of oxygen derivatives and mitochondrial superoxide levels, alleviation of superoxide dismutase and glutathione peroxidase activities reduction, and elimination of adverse effects of nickel in the nervous system (Xu et al., 2015). Astrocytes, which capable of producing taurine under proinflammatory signals, are responsible for changes in taurine levels after brain damage (Junyent et al., 2011). Taurine has been postulated that to reduce neurotoxicity and may be a promising target in the treatment of neurodegenerative diseases (Louzada et al., 2004; Paula-Lima et al., 2005). Cerebellum taurine content has been reported to decrease during the aging process in rats (Suárez et al., 2016). Taurine relieves streptozotocin-induced cognitive impairment via suppressing oxidative stress and inflammatory cytokines (Reeta et al., 2017). Caletti et al. (2018) set forth that long-term taurine treatment decreased oxidative stress, protects against DNA damage, and reduced inflammation in the diabetic rat brain.

Taurine has a potential neuroprotective effect via exhibiting antioxidative and mitochondria protective effects against manganese neurotoxicity (Ommati et al., 2019). In rats exposed to drinking water and sodium fluoride, taurine administration with oral gavage decreased the oxidative stress index in brain tissue, suppressed elevation in inflammatory biological markers, and reversed caspase-3 activity (Adedara et al., 2017). Taurine exhibit neuroprotective effects to dopaminergic neurons via inhibition of neuroinflammation which caused by microglia (Che et al., 2018). In a transgenic mouse model of Alzheimer's disease, administration of taurine via drinking water for 6 weeks has rescued cognitive deficits. Researchers have suggested that taurine can aid cognitive impairment and may inhibit $A \beta$-related damages
(Kim et al., 2014). Taurine has neuroprotective effects against glutamatergic antagonist-induced memory deficit and hyperlocomotion in zebrafish (Franscescon et al., 2020).

\section{Conclusion}

Both in vivo and in vitro researches have indicated that taurine has important effects on the central nervous system. Taurine has neurotrophic and neuroprotective effects by suppressing calpain activation through taurine receptors, coordinating gene expressions of neural stem and precursor cells, inhibiting sodium/calcium modifier, and endoplasmic reticulum stress-mediated apoptosis suppression. Taurine, which contributes to the proliferation and survival of neural progenitor cells, is a trophic factor for these cells. Taurine is involved in neural stem/progenitor cell proliferation in developing brain tissue and controls cell content and water content of neurons during ion entry and exit through membrane depolarization in neuronal transmissions. Taking into account the results of scientific studies based on the administration of taurine due to its neuroprotective effects, it is understood that taurine is an alternative option in the treatment of neurodegenerative diseases of both humans and animals

\section{References}

Adedara IA, Olabiyi BF, Ojuade TD, Idris UF, Onibiyo EM, Farombi EO, 2017: Taurine reverses sodium fluoridemediated increase in inflammation, caspase-3 activity, and oxidative damage along the brainpituitary-gonadal axis in male rats. Can J Physiol Pharmacol, 95, 1019-1029.

Ananchaipatana-Auitragoon $\quad \mathrm{P}, \quad$ AnanchaipatanaAuitragoon Y, Siripornpanich V, Kotchabhakdi N, 2015: Protective role of taurine in developing offspring affected by maternal alcohol consumption. EXCLI J, 14, 660-671.

Caletti G, Herrmann AP, Pulcinelli RR, Steffens L, Morás AM, Vianna P, Chies J, Moura DJ, Barros H, Gomez R, 2018: Taurine counteracts the neurotoxic effects of streptozotocin- induced diabetes in rats. Amino Acids, 50, 95-104.

Camargo RL, Batista TM, Ribeiro RA, Branco RC, Da Silva PM, Izumi C, Araujo TR, Greene LJ, Boschero AC, Carneiro EM, 2015: Taurine supplementation preserves hypothalamic leptin action in normal and protein-restricted mice fed on a high-fat diet. Amino Acids, 47, 2419-2435.

Cardin V, Lezama R, Torres-Márquez ME, PasantesMorales H, 2003: Potentiation of the osmosensitive taurine release and cell volume regulation by cytosolic $\mathrm{Ca}^{2+}$ rise in cultured cerebellar astrocytes. Glia, 44, 119-128. 
Chan CY, Sun HS, Shah SM, Agovic MS, Ho I, Friedman E, Banerjee SP, 2013: Direct interaction of taurine with the NMDA glutamate receptor subtype via multiple mechanisms. Adv Exp Med Biol, 775, 45-52.

Che Y, Hou L, Sun F, Zhang C, Liu X, Piao F, Zhang D, Li H, Wang $Q$, 2018: Taurine protects dopaminergic neurons in a mouse Parkinson's disease model through inhibition of microglial M1 polarization. Cell Death Dis, 9, 435.

Chen C, Yang Q, Ma X, 2020: Synergistic effect of ascorbic acid and taurine in the treatment of a spinal cord injury- induced model in rats. 3 Biotech, 10, 50.

De Luca A, Pierno S, Camerino DC, 2015: Taurine: The appeal of a safe amino acid for skeletal muscle disorders. J Transl Med, 13, 243.

Deleuze C, Duvoid A, Moos FC, Hussy N, 2000: Tyrosine phosphorylation modulates the osmosensitivity of volume-dependent taurine efflux from glial cells in the rat supraoptic nucleus. J Physiol, 2, 291-299.

Engelmann M, Ludwig M, Singewald N, Ebner K, Sabatier N, Lubec G, Landgraf R, Wotjak CT, 2001: Taurine selectively modulates the secretory activity of vasopressin neurons in conscious rats. Eur J Neurosci, 14, 1047-1055.

Foos TM, Wu JY, 2002: The role of taurine in the central nervous system and the modulation of intracellular calcium homeostasis. Neurochem Res, 27, 21-26.

Franscescon F, Müller TE, Bertoncello $\mathrm{KT}$, Rosemberg DB, 2020: Neuroprotective role of taurine on MK-801induced memory impairment and hyperlocomotion in zebrafish. Neurochem Int, 135, 104710.

Gharibani PM, Modi J, Pan C, Menzie J, Ma Z, Chen PC, Tao R, Prentice H, Wu JY, 2013: The mechanism of taurine protection against endoplasmic reticulum stress in an animal stroke model of cerebral artery occlusion and stroke-related conditions in primary neuronal cell culture. Adv Exp Med Biol, 776, 241258.

Gu Y, Zhao Y, Qian K, Sun M, 2015: Taurine attenuates hippocampal and corpus callosum damage, and enhances neurological recovery after closed head injury in rats. Neuroscience, 291, 331-340.

Hackett MJ, Paterson PG, Pickering IJ, George GN, 2016: Imaging Taurine in the Central Nervous System Using Chemically Specific X-ray Fluorescence Imaging at the Sulfur K-Edge. Anal Chem, 88, 10916-10924.

Hernández-Benítez R, Pasantes-Morales $H$, Saldaña IT, Ramos-Mandujano G, 2010: Taurine stimulates proliferation of mice embryonic cultured neural progenitor cells. J Neurosci Res, 88, 1673-1681.

Hernández-Benítez R, Ramos-Mandujano G, PasantesMorales H, 2012: Taurine stimulates proliferation and promotes neurogenesis of mouse adult cultured neural stem/progenitor cells. Stem Cell Res, 9, 24-34.

Huang X, Wu W, Hu P, Wang Q, 2018: Taurine enhances mouse cochlear neural stem cells proliferation and differentiation to sprial gangli through activating sonic hedgehog signaling pathway. Organogenesis, 4, 147-157.

Jangra A, Rajput P, Dwivedi DK, Lahkar M, 2020: Amelioration of repeated restraint stress- induced behavioral deficits and hippocampal anomalies with taurine treatment in mice. Neurochem Res, 45, 731-740.

Jia $F$, Yue $M$, Chandra D, Keramidas A, Goldstein PA, Homanics GE, Harrison NL, 2008: Taurine is a potent activator of extrasynaptic $\mathrm{GABA}(\mathrm{A})$ receptors in the thalamus. J Neurosci, 28, 106-115.

Junyent F, De Lemos L, Utrera J, Paco S, Aguado F, Camins A, Pallàs M, Romero R, Auladell C, 2011: Content and traffic of taurine in hippocampal reactive astrocytes. Hippocampus, 21, 185-197.

Kim HY, Kim HV, Yoon JH, Kang BR, Cho SM, Lee S, Kim JY, Kim JW, Cho Y, Woo J, Kim Y, 2014: Taurine in drinking water recovers learning and memory in the adult APP/PS1 mouse model of Alzheimer's disease. Sci Rep, 4, 7467.

Liu Y, Li F, Zhang L, Wu J, Wang Y, Yu H, 2017: Taurine alleviates lipopolysaccharide- induced liver injury by anti-inflammation and antioxidants in rats. Mol Med Rep, 16, 6512-6517.

Louzada PR, Paula Lima AC, Mendonca-Silva DL, Noël F, De Mello FG, Ferreira ST, 2004: Taurine prevents the neurotoxicity of beta-amyloid and glutamate receptor agonists: activation of GABA receptors and possible implications for Alzheimer's disease and other neurological disorders. FASEB J, 18, 511-518.

Menzie J, Prentice H, Wu JY, 2013: Neuroprotective mechanisms of taurine against ischemic stroke. Brain Sci, 3, 877-907.

Mersman B, Zaidi W, Syed NI, Xu F, 2020: Taurine promotes neurite outgrowth and synapse development of both vertebrate and invertebrate central neurons. Front Synaptic Neurosci, 12, 29.

Morales I, Dopico JG, Sabate M, Gonzalez-Hernandez T, Rodriguez M, 2007: Substantia nigra osmoregulation: taurine and ATP involvement. Am J Physiol Cell Physiol, 292, C1934-1941.

O'Byrne MB, Tipton KF, 2000: Taurine-induced attenuation of MPP+ neurotoxicity in vitro: a possible role for the GABA(A) subclass of GABA receptors. I Neurochem, 74, 2087-2093.

Oja SS, Saransaari P, 2013: Regulation of taurine release in the hippocampus of developing and adult mice. $A d v$ Exp Med Biol, 775, 135-143.

Olson JE, Martinho E Jr, 2006: Regulation of taurine transport in rat hippocampal neurons by hypoosmotic swelling. J Neurochem, 96, 1375-1389.

Ommati MM, Heidari R, Ghanbarinejad V, Abdoli N, Niknahad H, 2019: Taurine Treatment Provides Neuroprotection in a Mouse Model of Manganism. Biol Trace Elem Res, 190, 384-395.

Pan C, Prentice H, Price AL, Wu JY, 2012: Beneficial effect of taurine on hypoxia- and glutamate-induced endoplasmic reticulum stress pathways in primary neuronal culture. Amino Acids, 43, 845-855.

Pasantes-Morales H, Ramos-Mandujano G, HernándezBenítez R, 2015: Taurine enhances proliferation and promotes neuronal specification of murine and human neural stem/progenitor cells. Adv Exp Med Biol, 803, 457-472.

Paula-Lima AC, De Felice FG, Brito-Moreira J, Ferreira ST, 2005: Activation of $G A B A(A)$ receptors by taurine and muscimol blocks the neurotoxicity of beta- 
amyloid in rat hippocampal and cortical neurons. Neuropharmacology, 49, 1140-1148.

Rak K, Völker J, Jürgens L, Scherzad A, Schendzielorz $P_{1}$ Radeloff A, Jablonka S, Mlynski R, Hagen R, 2014 Neurotrophic effects of taurine on spiral ganglion neurons in vitro. Neuroreport, 25, 1250-1254.

Reeta KH, Singh D, Gupta YK, 2017: Chronic treatment with taurine after intracerebroventricular streptozotocin injection improves cognitive dysfunction in rats by modulating oxidative stress, cholinergic functions and neuroinflammation. Neurochem Int, 108, 146-156.

Ripps H, Shen W, 2012: Review: taurine: a "very essential" amino acid. Mol Vis, 18, 2673-2686.

Seki Y, Kimura M, Mizutani N, Fujita M, Aimi Y, Suzuki $Y_{\text {, }}$ 2005: Cerebrospinal fluid taurine after traumatic brain injury. Neurochem Res, 30, 123-128.

Shivaraj MC, Marcy G, Low G, Ryu JR, Zhao X, Rosales FJ, Goh EL, 2012: Taurine induces proliferation of neural stem cells and synapse development in the developing mouse brain. PLoS One, 7(8), e42935.

Sobrido-Cameán D, Fernández-López B, Pereiro $\mathrm{N}$, Lafuente A, Rodicio MC, Barreiro- Iglesias A, 2020: Taurine promotes axonal regeneration after a complete spinal cord injury in lampreys. I Neurotrauma, 37, 899-903.

Solís JM, Herranz AS, Herreras O, Lerma J, Martín del Río $R$, 1988: Does taurine act as an osmoregulatory substance in the rat brain? Neurosci Lett, 91, 53-58.

Suárez LM, Muñoz MD, Martín Del Río R, Solís JM, 2016: Taurine content in different brain structures during ageing: effect on hippocampal synaptic plasticity. Amino Acids, 48, 1199-1208.

Tiedemann F, Gmelin L, 1827: Einige neue Bestandtheile der Galle des Ochsen". Annalen der Physik, 85, 326337.

Vitvitsky V, Garg SK, Banerjee R, 2011: Taurine biosynthesis by neurons and astrocytes. J Biol Chem, 286, 32002-32010.

Vohra BP, Hui X, 2001: Taurine protects against carbon tetrachloride toxicity in the cultured neurons and in vivo. Arch Physiol Biochem, 109, 90-94.
Wade JV, Olson JP, Samson FE, Nelson SR, Pazdernik TL, 1988: A possible role for taurine in osmoregulation within the brain. J Neurochem, 51, 740-745.

Wang GH, Jiang ZL, Fan XJ, Zhang L, Li X, Ke KF, 2007: Neuroprotective effect of taurine against focal cerebral ischemia in rats possibly mediated by activation of both GABAA and glycine receptors. Neuropharmacology, 52, 1199-1209.

Wang Q, Zhu GH, Xie DH, Wu WJ, Hu P, 2015: Taurine enhances excitability of mouse cochlear neural stem cells by selectively promoting differentiation of glutamatergic neurons over GABAergic neurons. Neurochem Res, 40, 924-931.

Wu H, Jin Y, Wei J, Jin H, Sha D, Wu JY, 2005: Mode of action of taurine as a neuroprotector. Brain Res, 1038, 123-131.

Wu JY, Prentice H, 2010: Role of taurine in the central nervous system. J Biomed Sci, 24, 17 Suppl 1:S1.

Xu S, He M, Zhong M, Li L, Lu Y, Zhang Y, Zhang L, Yu Z, Zhou $Z, 2015$ : The neuroprotective effects of taurine against nickel by reducing oxidative stress and maintaining mitochondrial function in cortical neurons. Neurosci Lett, 590, 52-57.

Zhang B, Yang X, Gao X, 2010: Taurine protects against bilirubin-induced neurotoxicity in vitro. Brain Res, 1320, 159-167.

Zhang X, Wang X, Zhang J, Pan X, Jiang J, Li Y, 2017: Effects of taurine on alterations of neurobehavior and neurodevelopment key proteins expression in infant rats by exposure to hexabromocyclododecane. Ad Exp Med Biol, 975, 119-130.

Zhao H, Qu J, Li Q, Cui M, Wang J, Zhang K, Liu X, Feng H, Chen $Y$, 2018: Taurine supplementation reduces neuroinflammation and protects against white matter injury after intracerebral hemorrhage in rats. Amino Acids, 50, 439-451.

*Correspondens: Ayris GÖKÇEOĞLU

Department of Biochemistry, Faculty of Veterinary Medicine, Ondokuz Mayis University, Samsun, Turkey.

e-mail: ayrisalt@gmail.com 